\title{
The Impact of Energy Prices and Money Growth on Five Industrial Countries
}

\author{
R. W. HAFER
}

I

$N$ the winter of 1973-74, the Organization of Petroleum Exporting Countries (OPEC) quadrupled the price of oil from $\$ 3$ a barrel to about $\$ 12$ a barrel, a fourfold increase that, along with a marked slowing of money growth, precipitated one of the longest and deepest post-war declines in economic activity in most industrial nations. The subsequent recession was followed by a period of relatively rapid economic expansion in most of these nations, only to be halted by yet another explosion in energy prices in 1979 and 1980. Once again, it appears that this price increase has been accompanied by sharply reduced money growth.

This article discusses the impact of recent energy price changes and monetary growth on the economic performance of five major industrial countries: Canada, Germany, Japan, the United Kingdom and the United States. The analysis focuses on the growth of real output, industrial production and consumer prices, and changes in the level of the unemployment rate over the $1979-80$ period.

\section{ENERGY PRICES, MONEY GROWTH AND ECONOMIC ACTIVITY}

A rise in energy prices represents an increase in the cost of a significant productive input. Consequently, an increase in energy prices relative to other prices precipitates a decline in the amount of goods and services supplied by the economy at any given level of prices. ${ }^{1}$ A higher general price level is then necessary if the 1fohn A. Tatom, "Energy Prices and Short-Pun Economic
Performance," this Revieto (January 1980), pp. 3-17.

same amounts of labor (given a nominal wage rate), capital and energy inputs are to be used. Because of the increase in energy prices and the economic obsolescence of existing plant and equipment, however, producers will reduce their use of energy. The results of these related actions are a decline in real output and an increase in the price level. Thus, the level of prices consistent with maintaining full employment of labor and capital increases, and the actual and full-employment level of output (potential output) falls as a consequence of the energy price increase.

Just as an increase in the relative price of energy precipitates a reduction in economic activity, so a substantial decrease in the growth of the money supply relative to its trend path also leads to declining economic activity. For example, a significant reduction in money growth relative to trend has preceded almost every economic contraction in the United States since the latter part of the 19th century. ${ }^{2}$ Associated with these contractions are declines in production and concomitant increases in idle resources (i.e., unemployment). Thus, restrictive money growth, in the short-run, reduces the economy's output of goods and services. There is evidence, however, that the general level of prices is temporarily unaffected by such restrictive money growth. ${ }^{3}$

\footnotetext{
2See Milton Friedman and Anna J. Sehwartz "Money and Business Cycles," Review of Economics and Statistics (February 1963), pp. 32-64 and William Poole, "The Relationship of Monetary Decelerations to Business Cycle Peaks: Another Look at the Evidence," Journal of Finance (June 1975), pp. $697-712$.

SSee Keith M. Carlson, "The Lag from Money to Prices," this Revietw (October 1980), pp. 3 10.
} 


\section{Chart 1 \\ Relative Price of Energy to Final Users*}

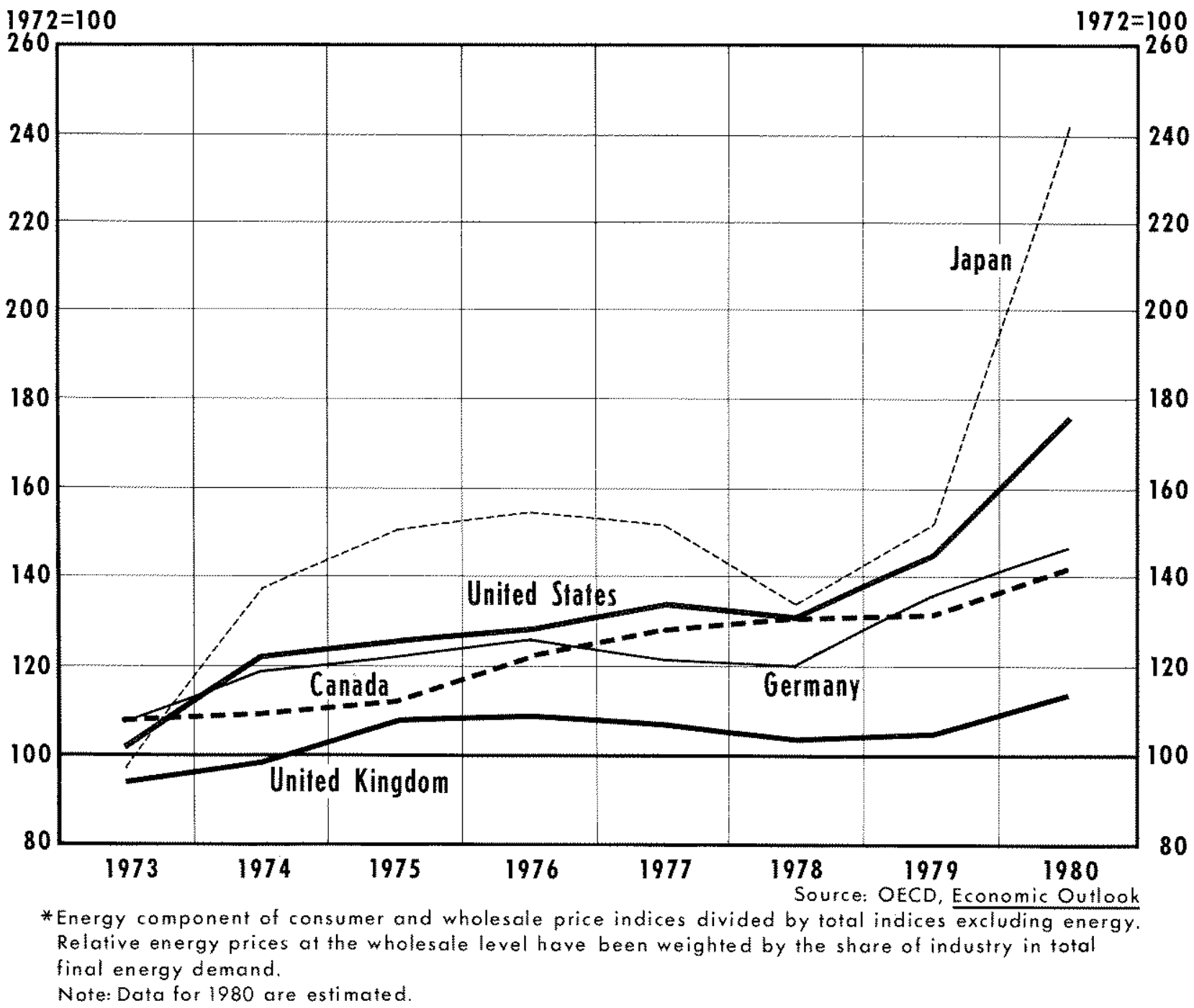

The 1973-74 and 1979-80 episodes of generally declining economic activity in the five countries are characterized by both higher relative energy prices and restrictive money growth. Consequently, the analysis presented above is necessary to understand the recent economic events. It will be evident that the relationships outlined above generally hold across the countries examined.

\section{INERGY PRICES}

Chart 1 shows what has happened to one measure of the relative price of energy - the ratio of energy prices (to final users) to the price of final goods for the five countries since $1972{ }^{4}$ The 1973-74 increase in OPEC oil prices is clearly shown in the general increase in relative energy prices: the simple average annual rate of increase during 1973-74 for the five countries was about 16 percent.

The recent boost in oil prices has again led to increases in relative energy prices. In the United States,

tThe relative prices of energy are computed by dividing the energy component of the wholesale and consumer price indices by the total index excluding the energy component. See Organization for Economic Co-Operation and Development (OECD) Economic Outlook (Decenber 1980), p. 52. 
Chart 2

\section{Money Growth}

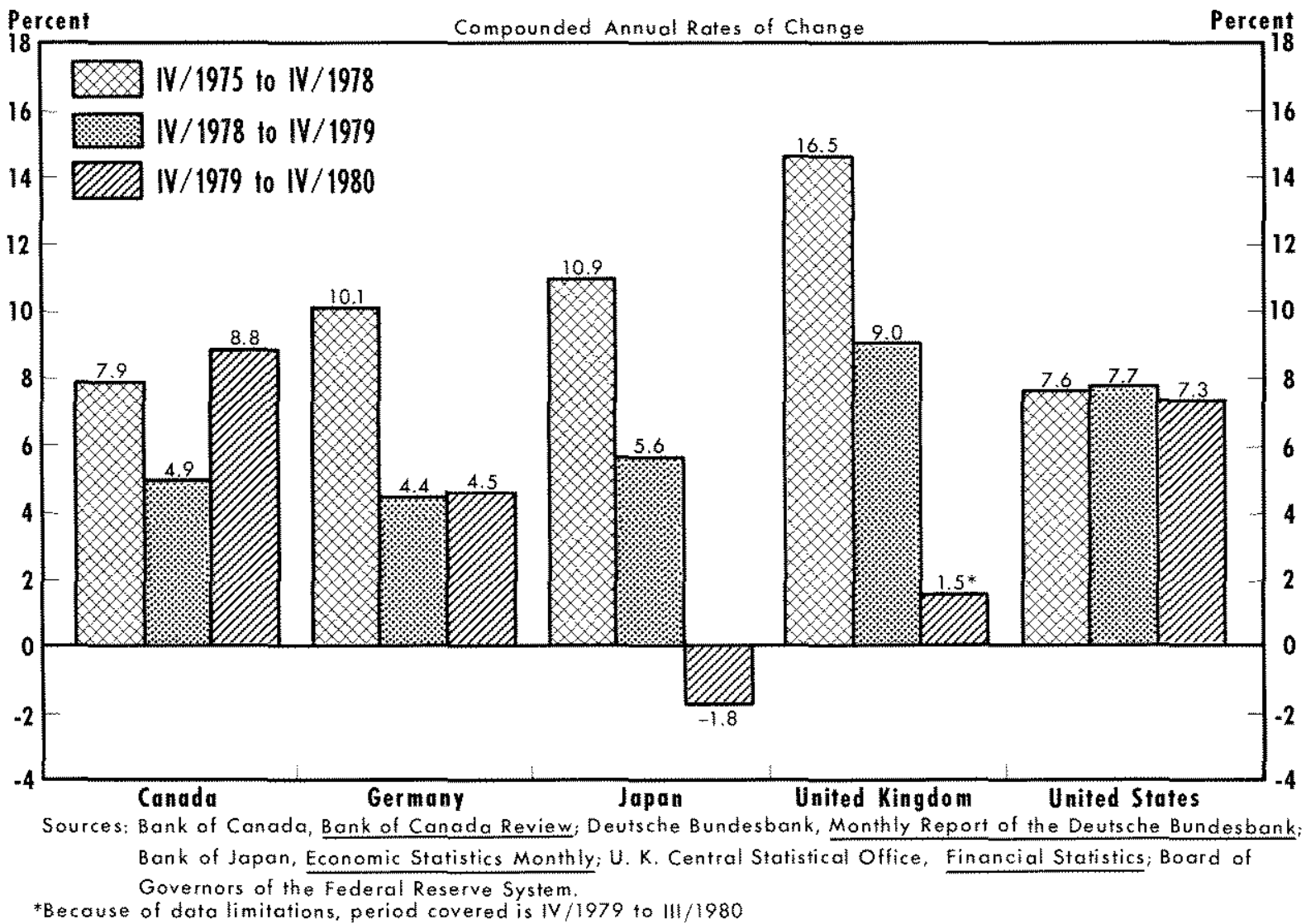

for example, relative energy prices increased at about a 20 percent annual rate during 1979-80; Canada, Germany and the United Kingdom sustained increases of about 8 percent. Just as in the 1973-74 period, the most dramatic increase occurred in Japan; relative energy prices increased at a 60 percent rate during $1979-80.5$

5Although there are similar movements in relative energy prices in chart 1 during the 1973-74 and 1978-80 periods, the observed differences are due to the varying impacts of higher oil prices across countries, Because the relative energy prices reported in chart 1 are based on the energy components of the wholesale and consumer price indices, the differential impact of a change in the price of oil can be explained by the speed at which prices of the energy and fuels constituting the indices' energy component adjust to the oil price increase. To do this, the change in the energy component of the wholesale price index is divided by the rise in the import price of oil. Because the coverage of the energy prices is not identi$\mathrm{cal}$, the ratio (known as the pass-through ratio) is not directly comparable actoss coumtries. They may, however, give an insight into the different countries' price response to the increased oil price.

The pass-through ratios calculated for the 1978-80 period suggest that the relatively larger increases in the relative

\section{MONETARY GROWTH}

The rise in oil prices during the 1973-74 period was accompanied by generally higher prices, reduced real economic output and lower growth of the money stock. The data in chart 2 reveal that the general response to the recent oil price shock again was to slow the growth of the money supply. Using the IV/1975-IV/1978 period for comparison, money stock growth has slowed considerably in Germany, Japan

price of energy to final users for the United States and Japan are explained by the fact that a given change in oil prices passes through each index's energy component faster than the others: the pass-through ratios are 0.69 and 0.81 respectively. The lower ratios for the United Kingdom $(0.51)$. Canada $(0.41)$ and Cermany $(0.29)$ suggest that the speed with which oil price increases feed into the energy component of the price index is less for these economies. These ratios are explained by differing responses of prices for competing fuels, changes in controls over both domestic production and pricing of competing fuels, and different tax structures on energy use in the countries.

For a complete description of the pass-through ratio, see OECD Economic Ottlook (December 1980), p. $31-53$. 
Chart 3

Real GNP

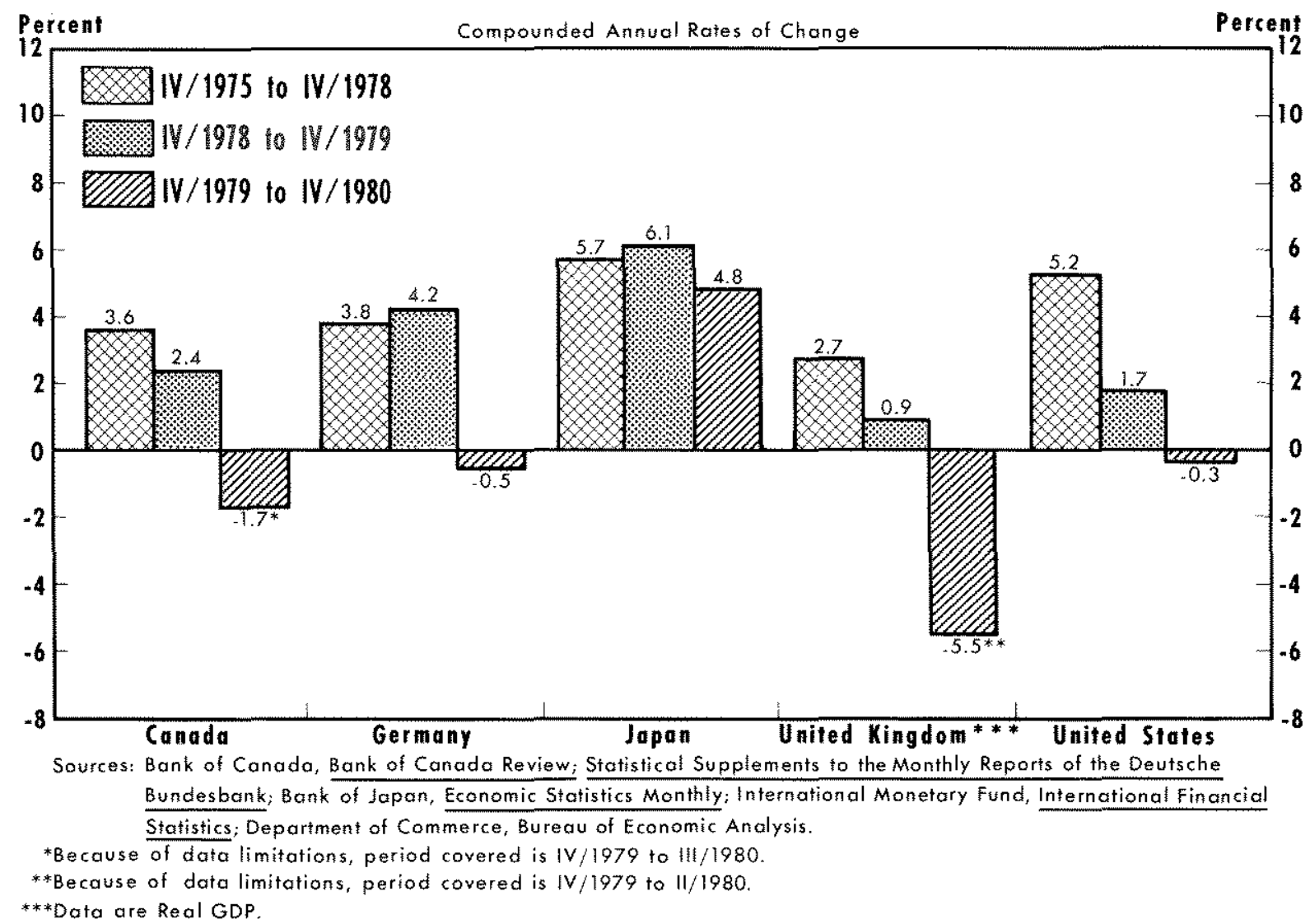

and the United Kingdom, while decreasing slightly in the United States. In contrast, Canada's money growth has actually been faster since IV/1979.

Chart 2 may not provide the most accurate description of the sharp declines in money growth instituted by the various governments. By examining money growth rates over shorter time intervals, the degree of monetary tightness is more fully revealed. Consider, for example, Canada and the United States. Chart 2 reveals no slowing in monetary growth for Canada and very little for the United States. From IV/1979 to II/1980, however, a far different picture emerges: the growth rate of money in Canada during this period is 1.6 percent; in the United States it is 1.8 percent. Each of these figures reveals a tightening in money growth relative to trend and, other things equal, portends a decline in economic activity.

Money growth was sharply reduced in all five countries up to the second quarter of 1980 . This is similar to the 1973-74 period and has produced a greater decline in economic activity than would have resulted from the energy shock alone. ${ }^{6}$

\section{ECONOMIC ACTIVITY}

\section{Real GNP}

The growth of an economy's real gross national product (real GNP) is a widely used indicator of an economy's overall economic performance. ${ }^{7}$ To illustrate the magnitude of the recent downtum in economic activity, chart 3 shows the growth rates of real GNP for the five countries during three time periods. The first period, IV/1975-IV/1978, is used as a reference period and represents the expansion phase of the

SSee John A. Tatom, "Energy Prices, Economic Performance and Monetary Policy," Federal Reserve Bank of St. Louis Working Paper No. 81-007 (1981), p. 34.

7 Gross national product is the total market value of all goods and services prodnced in the economy during a given period of time. Real GNP is this fagure adjusted for changes in prices. 


\section{Chart 4}

\section{Industrial Production}

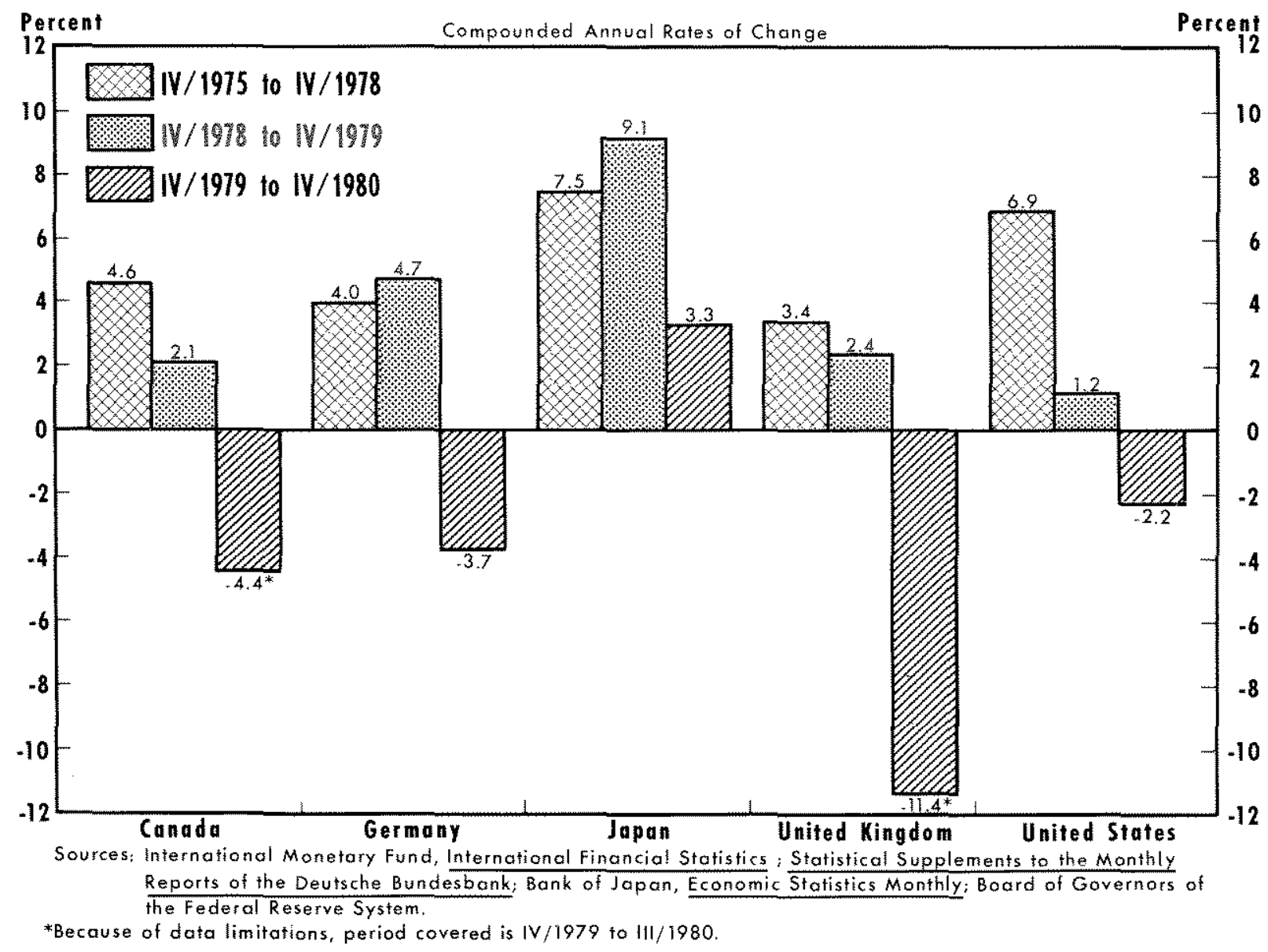

most recent business cycle. The other periods, IV/1978 IV/1979 and IV/1979-IV/1980, illustrate the general downturn in real GNP growth following both the sharp increase in energy prices and the reductions in money growth rates.

As chart 3 shows, Canada, the United Kingdom and the United States experienced marked deviations from previous real GNP growth in IV/1978-rV/1979. Of these three, the United States sustained the sharpest decline in real economic activity with a 3.5 percentagepoint decline in the growth rate of output compared to the preceding three-year period. The downturn in real economic growth is even more pervasive during IV/ 1979-IV/1980; all countries except Japan registered a negative growth in real GNP. Moreover, the data in chart 3 , since they are calculated for four-quarter periods, reduce the large fluctuations that actually took place in each country. For example, from $U / 1980$ to II/ 1980 , real GNP decreased at rates of 4.3 percent in Canada, 7.5 percent in Germany, 9.8 percent in the United Kingdom and 9.9 percent in the United States. In each case, these one-quarter rates of change were some of the largest declines in output growth in the post-war period.

Japan apparently has maintained much of its growth during the recent period. The most recent growth rate of 4.8 percent reflects only a slight decline from the previous 6.1 percent rate. Looking at the one-quarter growth rates, however, reveals a substantial slowing in Japan's real economic activity, much like the other countries: from I/1980 to II/1980, Japan's real output increased at only a 2.5 percent rate, down sharply from the previous quarter's expansion rate of 7.6 percent. Thus, Japan also has experienced a marked slowdown in its rate of output growth following the recent surge in energy prices and reduced money growth. 


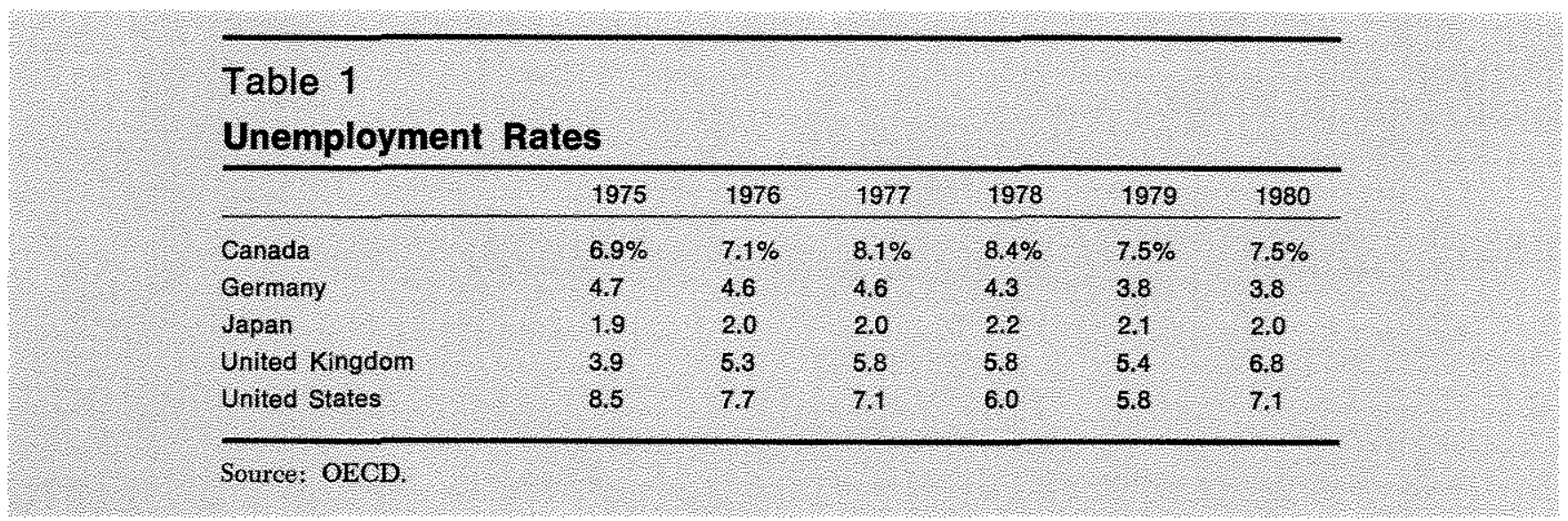

\section{Industrial Production}

The slowing in economic activity also is evidenced in industrial production growth (chart 4). Again, with the exception of Japan, the growth of industrial production (a measure of the output in the manufacturing, mining and utility sectors) has turned negative during the past year. The largest decline occurred in the United Kingdom with an 11.4 percent decrease in 1980.

Examining the quarterly growth rates reveals that each country experienced the largest decline in industrial production growth during the first few quarters of 1980: industrial production decreased, on average, at about a 10 percent rate from $\mathrm{I} / 1980$ to $\mathrm{I} / 1980 .^{8}$ Similarly, Japan's industrial production decreased at about a 9 percent rate from II $/ 1980$ to III $/ 1980$. The interesting feature of these figures is the coincidence among countries of the decline in industrial production, which suggests that the energy price shock, combined with similar monetary policies, have had similar impacts.

\section{Employment}

The unemployment rate typically declines during the expansion phase of the business cycle and increases during economic contractions, generally following economic activity with a short lag. The recent declines in the production of goods and services indicated in charts 3 and 4 suggest that unemployment has increased in these countries.

The association of output growth and unemployment is illustrated by the United States' experience

"The figures for each country are: Canada -10.2 percent; Gerw many, -9.0 percent; Japan, 0.6 percent; United Kingdom, -11.8 percent; and the United States, -19.2 percent. since 1975 (table 1). The unemployment rate, at 8.5 percent in 1975, declined throughout the next five years to a level of 5.8 percent in 1979 , then jumped to over 7 percent in 1980. Similarly, the jobless rate in the United Kingdom increased from 5.4 percent in 1979 to 6.3 percent in 1980 , a period of economic contraction.

The unemployment rates in the other countries have remained relatively stable duing the past few years. In Japan, for example, the unemployment rate remained near 2,0 percent throughout 1975-80. In Germany, on the other hand, the reported unemployment rate actually has declined during this period.

The differences in labor market response to a downturn in economic activity can be explained by different institutional factors among the countries. Figures on German unemployment data, for example, do not include "guest workers" (temporary foreign workers). The impact of this group on the reported statistics is shown in the unemployment rate for 1977 that includes the approximately 440,000 guest workers who emigrated from Germany: 6.4 percent. $^{9}$ This figure is significantly larger than the 4.6 percent reported in table 1 , an indication of the difficulties that intercountry differences in data reporting cause in measuring the actual rise in unemployment accompanying a decline in economic activity.

\section{INFLATION}

A sustained increase in the general level of prices is determined primarily by previous money growth over an extended period of time. Short-term deviations of

9The Effect of OPEC Oil Pricing on Output, Prices and Exchange Rates in the United States and Other Industrialized Countries, Congressional Budget Office (February 1981), p. 61 . 


\section{Chart 5}

\section{Consumer Prices}

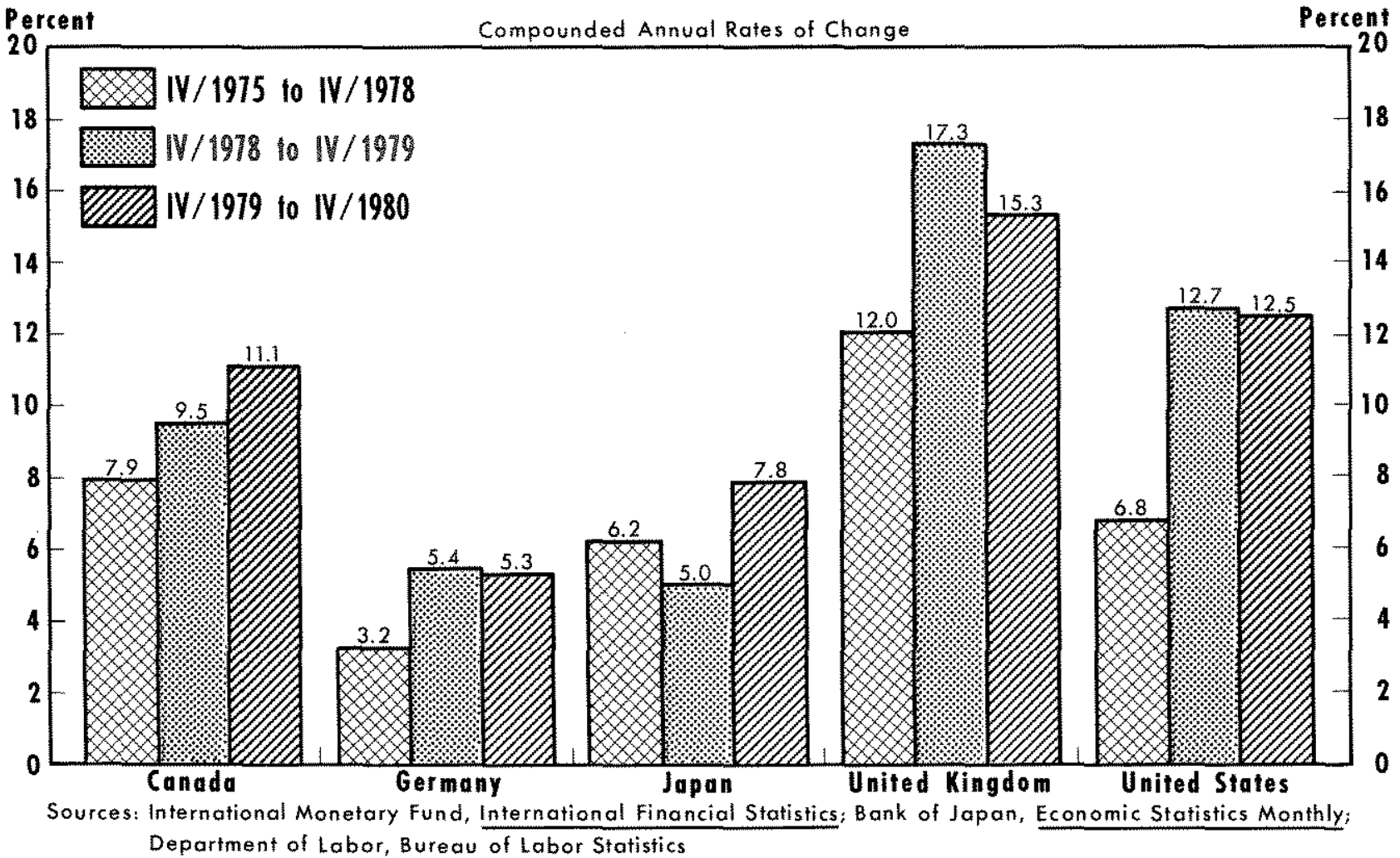

changes in the price level from this underlying, or monetary, rate of inflation occur for a variety of reasons. One example is the sharp increase in the price of energy relative to other goods caused by OPEC actions. ${ }^{10}$ Thus, the energy price increases during 1973-74 and 1979-80 precipitated declining real economic output and increases in the price level. ${ }^{11}$

As illustrated in chart 5, with the exception of the United Kingdom, consumer prices increased at relatively moderate rates from IV/1975 to IV/1978. With the exception of Germany and Japan, the inflation rates have reached double-digit levels over the IV/ 1978-IV/1980 period following the recent oil price shock. ${ }^{12}$

10For a discussion of the theory underlying this proposition and its application to the 1971-1976 period in the United States, see Denis S. Karnosky, "The Link Between Money and Prices - 1971-1976," this Review (June 1976), pp $17-23$

11Empirical evidence supporting this claim is presented in Tatom, "Energy Prices and Short-Run Economic Perfotmance."

12The recent increase in the inflation rate in the face of declining economic activity is a phenomenon similar to that of the last downturn. For a discussion of this period, see
Changes in the rate of inflation across the countries examined in chart 5 imply certain changes in foreign exchange markets. Exchange rate movements result from changes in the relative prices of foreign and domestic goods. If, for example, foreign goods become less costly relative to domestic goods (i.e., the foreign inflation rate is less than the domestic rate), the demand for foreign goods and, hence, foreign money rises. Consequently, the international value of the domestic currency falls with respect to the foreign currency.

This relationship between relative price movements and exchange rate movements is verified by foreign exchange market developments in the 1979-80 period. As an example, the difference between the inflation rates in the United States and Canada in 1979 was about 3 percentage points ( 12.7 percent minus 9.5 percent). In 1980 , however, this difference fell to about 1.5 percentage points. As the foregoing discussion suggests, the U.S. dollar appreciated (increased

Donald S. Kernp, "Economic Activity in Ten Major Industrial Countries: Late 1973 through Mid-1976," this Review (October 1976), pp. 8-15. 
in value) with respect to the Canadian dollar. Calculating the inflation differentials from the data in chart 5 , we find that the relative rate of inflation declined when compared to Germany and Japan in the 1979-80 period. In contrast, inflation increased in the United States compared to the United Kingdom over the period. With the exception of Japan, the relationship described above is supported: the U.S. dollar appreciated against the German deutschemark and depreciated against the English pound during the 1979-80 period.

\section{CONCLUSION}

Recent actions taken by OPEC have increased sharply the relative price of energy in the five industrial countries examined in this article. Monetary growth followed a generally restrictive pattern in 1979-80, similar to that in 1973-74. As a consequence of both OPEC actions and reduced money growth, the economies of Canada, Germany, Japan, the United Kingdom and the United States have been burdened with declines in real GNP and rising rates of inflation during the past two years. In Canada, the United Kingdom and the United States, unemployment rates have remained abnormally high or have increased in recent years.

Periods of declining economic activity and rising prices create problems in selecting the appropriate monetary policy response. A sharp, prolonged decrease in money growth intended to inhibit upward pressure on prices due to rising energy prices will aggravate the decline in real economic activity. On the other hand, an increase in money growth intended to offset the decline in real GNP will contribute to even greater future inflation. One recent study indicates that, with no change in money growth, rising energy prices will affect the rate of inflation only temporarily. Moreover, increasing the rate of growth of money only temporarily reduces the increased unemployment that accompanies the slowdown. ${ }^{13}$ This suggests that stable money growth may well be the correct response to such supply shocks.

13Tatom, "Energy Prices and Short-Run Economic

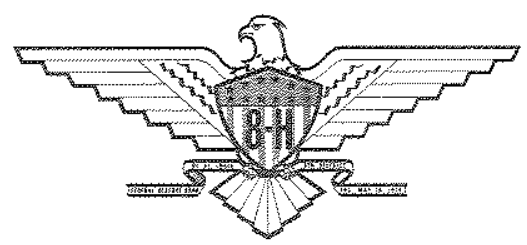

